\title{
Reliability and Factorial Validity of the Turkish Version of the Pain Disability Index in Rheumatic Patients With Chronic Pain
}

\author{
Mustafa UĞURLU, ${ }^{1}$ Görkem Karakaş UĞURLU, ${ }^{2}$ Şükran ERTEN, ${ }^{3}$ \\ Semra ULUSOY KAYMAK, ${ }^{1}$ Ali ÇAYKÖYLÜ² \\ ${ }^{1}$ Department of Psychiatry, Ankara Atatürk Training and Research Hospital, Ankara, Turkey \\ ${ }^{2}$ Department of Psychiatry, Medical Faculty of Yildırım Beyazıt University, Ankara, Turkey \\ ${ }^{3}$ Department of Rheumatology, Medical Faculty of Yildırım Beyazit University, Ankara, Turkey
}

\begin{abstract}
Objectives: This study aims to evaluate the reliability, factor structure, and validity of the Turkish version of the Pain Disability Index (PDI) in patients with chronic pain.

Patients and methods: The PDI Index was translated into Turkish according to the standard procedures and performed on 212 rheumatic patients

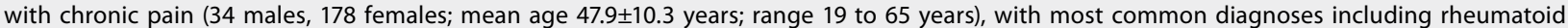
arthritis, seronegative spondyloarthropathies, and familial Mediterranean fever. Exploratory and confirmatory factor analyses were used for validation and Cronbach's alpha coefficient was determined as the internal reliability of the PDI. Correlations between each item and item-total score were also calculated.

Results: The Turkish form of the PDI revealed a two-factor model. Cronbach's alpha for the total scale was found as 0.86 . All items were correlated significantly with the total score, with values ranging from 0.73 to 0.81 . An analysis of the confirmatory factor revealed that the model fit was adequate.

Conclusion: The Turkish version of PDI had adequate psychometric properties in rheumatic patients with chronic pain. Thus, it may be useful in clinical practice to assist in better understanding of diseases characterized by chronic pain, providing objective measures for functional deficits, and monitoring treatment or rehabilitation effects.

Keywords: Disability; pain; reliability; validity.
\end{abstract}

Pain persisting for more than six months is referred to as "chronic pain." Chronic pain tends to continue despite treatment and not only affects the age at which people can continue to work, but also increases morbidity and hospital admission, and reduces participation in activities and quality of life. ${ }^{1-3}$ There have been studies showing that pain, especially chronic pain, may cause disabilities to various degrees. ${ }^{4,5}$

Disability is important for measuring disease burden and evaluating the effectiveness of health interventions. Pain-related disability is how well an individual is able to function in general areas of life and is poorly related to pathophysiology. It is much better correlated with the extent of pain and psychological distress in rheumatic patients with chronic pain. However, defining and measuring disability have been challenging. ${ }^{6-9}$

There are various symptoms causing disability in rheumatic diseases such as joint movement restriction, fatigue, weakness, pain, neurological symptoms, and other organ/system involvement. Most of the scales for assessing disability in rheumatic diseases focus on the entire disease rather than one symptom, whereas knowing which symptoms are responsible for the disability 
is important for clinical management. In Turkey, there are many scales assessing disability and quality of life; however, there is no adequate instrument for measuring pain-related disability in rheumatic diseases. The Pain Disability Index (PDI) is a simple and rapid instrument for measuring the impact the pain has on the ability of a person to participate in basic life activities. ${ }^{10}$ Therefore, in this study, we aimed to evaluate the reliability, factor structure, and validity of the Turkish version of the PDI in patients with chronic pain.

\section{PATIENTS AND METHODS}

The study included 212 patients (34 males, 178 females; mean age $47.9 \pm 10.3$ years; range 19 to 65 years) with rheumatologic diseases and chronic pain symptoms. ${ }^{11}$ The inclusion criteria were as follows; 18 to 65 years of age, outpatient follow-up for at least one year in rheumatology clinic, and pain continuing for the past six months comprising at least three of the following properties; (i) affecting one or more joints or body region, (ii) worsening with motion or touch, (iii) symptomatically improving after mild exercise, but worsening after heavy exercise, (iv) symptomatically worsening in response to climatic factors such as air pressure and humidity, $(v)$ symptomatically improving in response to warming of the affected regions, and (vi) well-localization. The exclusion criteria were as follows; other medical conditions that might cause chronic pain, patients with severe diseases requiring care or with severe mental illnesses. The study protocol was approved by the Yildirim Beyazit University Ethics Committee. A written informed consent was obtained from each patient. The study was conducted in accordance with the principles of the Declaration of Helsinki.

Developed by Raymond C. Tait, the PDI is a selfreporting questionnaire that measures the degree to which pain presently interferes with living in the following seven areas; family and/or home responsibilities, leisure activity, social activity, occupation, sexual behavior, self-care, and lifesupport activities. To complete the PDI, the respondent uses an 11-point scale ranging from 0 (no disability) to 10 (total disability). A total score is obtained by summing the responses to the seven items. $^{10}$
The PDI was translated from its original English version into Turkish according to a standardized procedure described previously. ${ }^{12,13}$ In the first step, PDI was translated into Turkish and this translations were combined into final version by two native Turkish speakers. In second step, final Turkish version of the questionnaire was translated back into English by other researchers. In third step, all of the researchers of the study evaluated the entire Turkish PDI version and approved the pre-final version. Ten patients with a rheumatologic disease performed the pre-final version and all of them were asked if they were able to understand and interpret the questions clearly and correctly. Their answers were discussed among the study researchers and the Turkish version was finalized (see the appendix in page 271).

Pain was the main factor causing disability in our study. The symptoms other than pain in rheumatic diseases were not considered on the PDI. Questions of PDI evaluate the disability caused by pain. Therefore, we included rheumatic patients with chronic pain instead of just one rheumatic disease. Also, we created the study sample taking into account the epidemiology of rheumatic diseases such as sex and prevalence.

Patients were given written instructions to respond to the PDI, a visual analog scale (VAS) for pain severity, and the Brief Disability Questionnaire (BDQ). Patients also answered questions that screened for sociodemographic characteristics, current medical and/or psychiatric problems, total duration of chronic pain, and analgesic use.

The VAS was used to measure pain severity. VAS is a common instrument used worldwide with tested validity and reliability. ${ }^{14}$ Patients with chronic pain were instructed to make an assessment by considering their ongoing pain over the last week.

The BDQ was developed based on the disability-related questions of the General Health Survey Short Form in order to evaluate physical and social disability. ${ }^{15}$ The Turkish reliability and validity of the BDQ were also performed. ${ }^{16}$

\section{Statistical analysis}

The sampling adequacy was determined using tests including Kaiser-Meyer-Olkin and Barlett's 
test of sphericity. An exploratory factor analysis (principal component analysis with varimax rotation, and the number of factor was determined according to an eigenvalue $>1$ and/or to explain more than $10 \%$ of the total variance) and a confirmatory factor analysis (maximum likelihood estimation) were performed for the PDI. The goodness-of-fit was evaluated using four criteria; the goodness-of-fit index, comparative fit index, the root-mean-square error of approximation, and the ratio of the chi-squared value to its degrees of freedom $\left(\chi^{2} / \mathrm{df}\right)$. To determine the convergent validity of the $\mathrm{PDI}$, the relations between the VAS and the BDQ were examined using the Pearson correlation technique. Cronbach's alpha coefficient, test-retest and the split-half method were also used for testing the reliability of the entire PDI scale. Floor and ceiling effects were examined by considering the number of individuals that obtained the lowest (0) or highest (70) scores possible and were assumed to be present if more than $15 \%$ of the participants achieved the highest or lowest score. ${ }^{17}$

Table 1. Sociodemographic and clinical characteristics of study sample $(n=212)$

\begin{tabular}{|c|c|c|c|}
\hline & $\mathrm{n}$ & $\%$ & Mean \pm SD \\
\hline Age (years) & & & $47.9 \pm 10.3$ \\
\hline \multicolumn{4}{|l|}{ Sex } \\
\hline Male & 34 & & \\
\hline Female & 178 & & \\
\hline \multicolumn{4}{|l|}{ Marital status } \\
\hline Married & 194 & & \\
\hline Single & 12 & & \\
\hline Divorced & 6 & & \\
\hline \multicolumn{4}{|l|}{ Education } \\
\hline Primary school & 145 & & \\
\hline High school & 46 & & \\
\hline University & 21 & & \\
\hline \multicolumn{4}{|l|}{ Diagnosis } \\
\hline $\mathrm{RA}$ & 85 & 40.1 & \\
\hline AS & 24 & 11.3 & \\
\hline Other SSpA & 41 & 19.3 & \\
\hline pSS & 14 & 6.6 & \\
\hline CTD & 13 & 6.1 & \\
\hline FMF & 11 & 5.2 & \\
\hline SLE & 4 & 1.9 & \\
\hline Others & 17 & 8.0 & \\
\hline Duration of disease & & & $8.8 \pm 7.0$ \\
\hline VAS & & & $60.4 \pm 23.0$ \\
\hline BDQ-T & & & $11.7 \pm 4.8$ \\
\hline PDI-T & & & $29.5 \pm 16.3$ \\
\hline \multicolumn{4}{|c|}{$\begin{array}{l}\text { SD: Standard deviation; RA: Rheumatoid arthritis; AS: Ankylosing } \\
\text { spondylitis; SSpA: Seronegative spondyloarthropathies; pSS: Primary } \\
\text { Sjögren's syndrome; CTD: Connective tissue disease; FMF: Familial } \\
\text { Mediterranean fever; SLE: Systemic lupus erythematosus; VAS: Visual } \\
\text { analog scale; BDQ-T: Brief Disability Questionnaire total score; PDI-T: Pain } \\
\text { disability index total score. }\end{array}$} \\
\hline
\end{tabular}

\section{RESULTS}

Demographic and clinical characteristics of the participants are shown in Table 1. The most common diagnoses were rheumatoid arthritis (41.9\%) and seronegative spondyloarthropathies (30.6). Ceiling and floor effects were not detected (Table 1, Figure 1).

Cronbach's alpha was used for internal consistency analysis of the PDI and determined to be $r=0.86$ for the entire test. For the two factors, Cronbach's alpha values were 0.82 (discretionary activity) and 0.80 (obligatory activity). None of the Cronbach's alpha values improved when any item was deleted. The split-half reliability of the scale (Spearman-Brown correction) was 0.78. The testretest method was used to determine the reliability of the scale, and the PDI was repeated for this purpose about one month after the first test on 30 randomized patients from among the original sample of participants. There were no significant differences in sex ratio, education level, mean age, and BDQ and VAS total scores between the random subgroup and the study sample. We found that the test-retest Pearson correlation coefficient of the scale's total score was 0.75 ( $p<0.001$ and bootstrapped $95 \%$ confidence interval of 0.511-0.878). The inter-item and item total and subscale correlations are listed in Table 2.

The Barlett's test of sphericity indicated that the PDI items were interdependent: Chi-square $(21)=681.2, \quad p<0.001$. The Kaiser-MeyerOlkin measure of sample adequacy was 0.862 . Exploratory factor analysis provided a two-factor

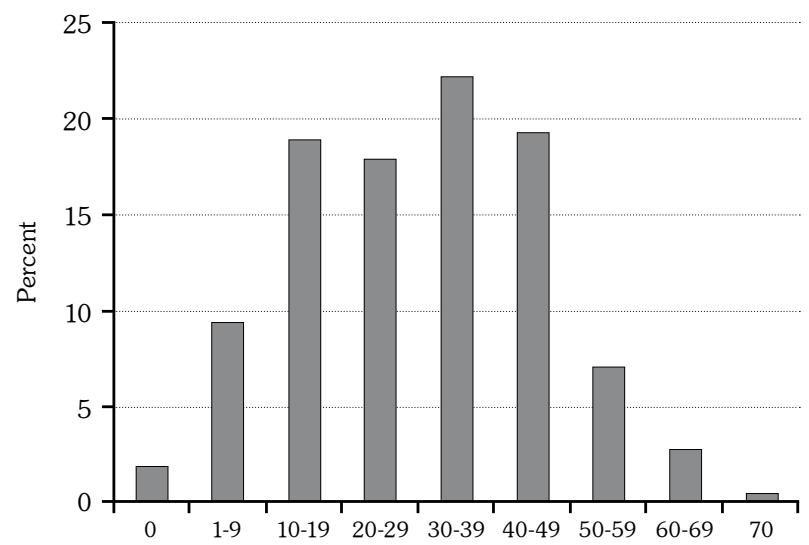

Figure 1. Floor and ceiling effect. Categorical version of pain disability index scores. 


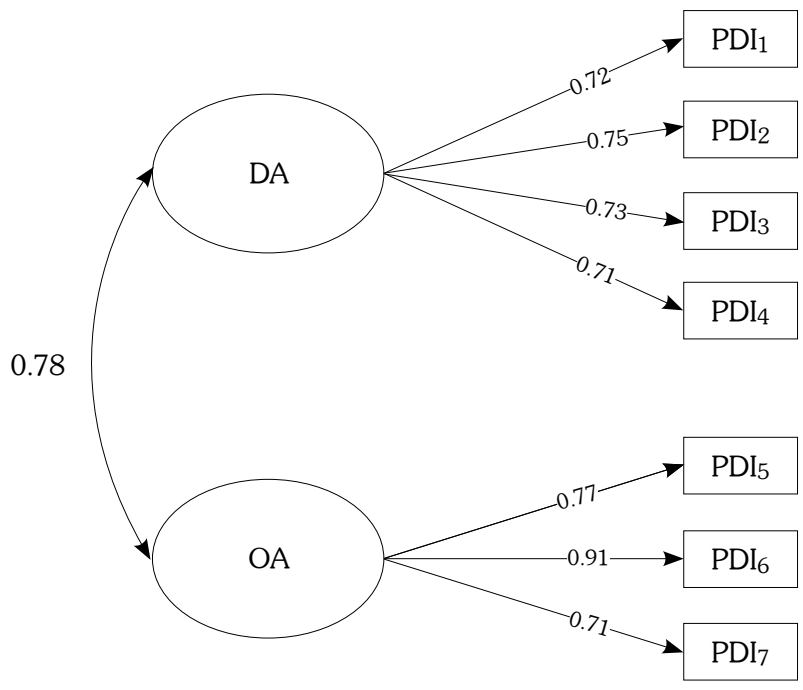

Figure 2. Confirmatory factor analysis for pain disability index and standard regression weight. PDI: Pain disability index; DA: Discretionary activity; OA: Obligatory activity.

model. The first factor accounted for $57.4 \%$ of the total variance and the second factor accounted for $12.3 \%$ of the total variance. The two-factor model accounted for $69.8 \%$ of the total variance. Factor 1 (discretionary activities) consisted of items 1, 2, 3 and 4; while factor 2 (obligatory activities) consisted of items 5, 6 and 7. Confirmatory factor analysis was used and the results were as follows; goodness-of-fit index $=0.972$, comparative fit index $=0.985, \chi^{2} / \mathrm{df}=1.79$, and root-mean-square error of approximation $=0.061$ (Figure 2).

Convergent validity was assessed as a result of an examination of the relationships among PDI, VAS, and BDQ total scores using correlation analysis. According to this analysis, there was a significant correlation between PDI and VAS $(r=0.539$ and $p<0.001)$ and PDI and BDQ $(r=0.309$ and $p<0.001)$ (Table 2). Summary of our results with the other adaptation studies are shown in Table 3.

\section{DISCUSSION}

It is important to properly assess the level of disability according to the factors causing the disability. Therefore, in this study, the psychometric properties of the Turkish version of the PDI that measures the level of pain related disability were examined in patients with chronic pain. Our study revealed a successful translation of the PDI into Turkish. The translation was shown to have good reliability (Cronbach's alpha $=0.86$, test-retest correlation $=0.75$ ). In the original scale development study, Tait et al. ${ }^{18}$ found the internal consistency of the scale to be $r=0.86$. The test-retest reliability $(r=0.91)$ within a week of the PDI administration was studied by Gronblad et al. ${ }^{19}$ In various studies, Cronbach's alpha of the PDI was found to be between 0.79 and $0.89 .^{10,19-23}$

In our study, factor analysis yielded a two-factor solution that accounted for $69.8 \%$ of the total variance. The first factor explained $57.4 \%$ of the total variance, while the second factor explained $12.3 \%$ of the total variance. These results are similar to those of Tait et al. ${ }^{18}$ According to the confirmatory factor analysis, the two-factor model fit was sufficient. Although concerns about

Table 2. Correlations among pain disability index total scores, subscale scores, inter-items and other scales

\begin{tabular}{|c|c|c|c|c|c|c|c|c|c|}
\hline & PDI total & DA & $\mathrm{OA}$ & $\mathrm{PDI}_{1}$ & $\mathrm{PDI}_{2}$ & $\mathrm{PDI}_{3}$ & $\mathrm{PDI}_{4}$ & $\mathrm{PDI}_{5}$ & $\mathrm{PDI}_{6}$ \\
\hline & $\mathrm{r}$ & $\mathrm{r}$ & $\mathrm{r}$ & $\mathrm{r}$ & $\mathrm{r}$ & $\mathrm{r}$ & $\mathrm{r}$ & $\mathrm{r}$ & $\mathrm{r}$ \\
\hline Brief Disability Questionnaire & 0.309 & & & & & & & & \\
\hline Visual analog scale & 0.539 & & & & & & & & \\
\hline Discretionary activity (factor 1) & 0.933 & & & & & & & & \\
\hline Obligatory activity (factor 2) & 0.873 & 0.638 & & & & & & & \\
\hline \multicolumn{10}{|l|}{ Pain Disability Index } \\
\hline 1 & 0.740 & 0.787 & 0.515 & & & & & & \\
\hline 2 & 0.775 & 0.819 & 0.547 & 0.577 & & & & & \\
\hline 3 & 0.752 & 0.802 & 0.522 & 0.453 & 0.545 & & & & \\
\hline 4 & 0.739 & 0.815 & 0.474 & 0.529 & 0.504 & 0.588 & & & \\
\hline 5 & 0.745 & 0.525 & 0.878 & 0.422 & 0.427 & 0.447 & 0.399 & & \\
\hline 6 & 0.816 & 0.644 & 0.871 & 0.541 & 0.528 & 0.549 & 0.461 & 0.711 & \\
\hline 7 & 0.730 & 0.523 & 0.852 & 0.411 & 0.487 & 0.394 & 0.391 & 0.546 & 0.640 \\
\hline
\end{tabular}


Table 3. Psychometric properties of pain disability index for different languages

\begin{tabular}{|c|c|c|c|c|c|c|}
\hline $\begin{array}{l}\text { Language } \\
\text { (references) }\end{array}$ & $\begin{array}{l}\text { Country } \\
\text { (date) }\end{array}$ & Sample & $\mathrm{n}$ & $\begin{array}{l}\text { PDI total/subscale } \\
\text { Mean } \pm \text { SD }\end{array}$ & $\alpha^{\ddagger} / \mathrm{ICC}$ & Factor structure \\
\hline Turkish* & Turkey & $\begin{array}{l}\text { Patients with } \\
\text { chronic pain }\end{array}$ & 212 & $29.5 \pm 16.3$ & 0.86 & Two-factor \\
\hline Turkish ${ }^{[23]}$ & $\begin{array}{l}\text { Turkey } \\
(2005)\end{array}$ & $\begin{array}{l}\text { Patients with } \\
\text { chronic low } \\
\text { back pain }\end{array}$ & 83 & $20.3 \pm 12.9$ & 0.84 & - \\
\hline Persian ${ }^{[18]}$ & $\begin{array}{l}\text { Iran } \\
(2010)\end{array}$ & $\begin{array}{l}\text { Patients with } \\
\text { low back pain }\end{array}$ & 304 & $\begin{array}{c}\text { Female }=26.1 \pm 15.5 \\
\text { Male }=22.4 \pm 13.2\end{array}$ & 0.86 & - \\
\hline Malay ${ }^{[24]}$ & $\begin{array}{l}\text { Malaysia } \\
(2010)\end{array}$ & $\begin{array}{l}\text { Patients with } \\
\text { chronic pain }\end{array}$ & 80 & $\begin{array}{l}\text { Item } 1=5.6 \pm 1.2 \\
\text { Item } 2=5.6 \pm 1.5 \\
\text { Item } 3=4.6 \pm 1.2 \\
\text { Item } 4=5.8 \pm 1.2 \\
\text { Item } 5=3.9 \pm 1.2 \\
\text { Item } 6=5.3 \pm 1.4 \\
\text { Item } 7=4.9 \pm 1.7\end{array}$ & 0.79 & One factor \\
\hline French $^{[20]}$ & $\begin{array}{l}\text { Canada } \\
(2008)\end{array}$ & $\begin{array}{c}\text { Musculoskeletal } \\
\text { condition (back/neck) }\end{array}$ & 176 & $\begin{array}{c}\text { Female }=36.1 \pm 14.7 \\
\text { Male }=34.3 \pm 12.8 \\
\text { Total PDI }=35.7\end{array}$ & 0.83 & Two-factor \\
\hline Finnish ${ }^{[17]}$ & $\begin{array}{c}\text { Finland } \\
\text { (1993) }\end{array}$ & $\begin{array}{l}\text { Patients with chronic } \\
\text { low back pain }\end{array}$ & 94 & - & 0.91 & Two-factor \\
\hline English $^{[10]}$ & $\begin{array}{l}\text { U.S.A } \\
(1990)\end{array}$ & $\begin{array}{l}\text { Patients with } \\
\text { chronic pain }\end{array}$ & 444 & $\begin{array}{l}\text { Low disability }=34.5 \pm 9.3 \\
\text { High disability }=55.9 \pm 5.7\end{array}$ & 0.86 & $\begin{array}{l}\text { Analysis 1: one factor } \\
\text { Analysis 2: Two-factor }\end{array}$ \\
\hline Dutch $^{[21]}$ & $\begin{array}{l}\text { Netherlands } \\
\text { (2013) }\end{array}$ & Acute back pain & 178 & $38.0 \pm 15.9$ & 0.89 & One-factor structure \\
\hline Dutch $^{[21]}$ & $\begin{array}{l}\text { Netherlands } \\
\text { (2013) }\end{array}$ & $\begin{array}{l}\text { Chronic low } \\
\text { back pain }\end{array}$ & 425 & $36.5 \pm 13.8$ & 0.85 & One-factor structure \\
\hline Dutch $^{[21]}$ & $\begin{array}{l}\text { Netherlands } \\
\text { (2013) }\end{array}$ & Widespread pain & 365 & $41.4 \pm 10.9$ & $\begin{array}{l}\mathrm{F} 1=0.83 \\
\mathrm{~F} 2=0.58\end{array}$ & Two-factor structure \\
\hline
\end{tabular}

the reliability of factor 2 (obligatory activities) are low, in our study, Cronbach's alpha of both factors (0.82 and 0.80) were sufficient, and, as expected, ${ }^{24}$ all factor loadings were greater than 0.7 .

Although the majority of our study participants' being females seems to be a limitation, rheumatic diseases have high female/male ratios. Therefore, the high female ratio of participants in the study sample might have contributed to the generalizability of our results as the study sample represents the population properly.

In the study of Biçer et al. ${ }^{25}$ in Turkey, Cronbach's alpha of the PDI was found to be 0.84 . However, our investigation is characterized by more reliable and generalizable results thanks to our larger sample size (212 participants in our study versus 83 in Biçer's study), higher item total correlation, and inclusion of a variety of musculoskeletal diseases that cause chronic pain; whereas in Biçer's study, the sample consisted of patients with low back pain. Furthermore, our use of exploratory and confirmatory factor analysis increased the strength of our results.

In conclusion, the Turkish version of the PDI had adequate psychometric properties in rheumatic patients with chronic pain, in terms of its internal consistency, test-retest reliability, convergent validity, and factorial structure. Thus, it may be useful in clinical practice to assist in better understanding of diseases characterized by chronic pain, providing objective measures for functional deficits, and monitoring treatment or rehabilitation effects.

\section{Acknowledgements}

We would like to thank Mr. Raymond C. Tait who developed the original PDI scale. 


\section{Declaration of conflicting interests}

The authors declared no conflicts of interest with respect to the authorship and/or publication of this article.

\section{Funding}

The authors received no financial support for the research and/or authorship of this article.

\section{REFERENCES}

1. Asghari A, Nicholas MK. Pain self-efficacy beliefs and pain behaviour. A prospective study. Pain 2001;94:85100.

2. McCracken LM, Zhao-O'Brien J. General psychological acceptance and chronic pain: there is more to accept than the pain itself. Eur J Pain 2010;14:170-5.

3. Torrance N, Elliott AM, Lee AJ, Smith BH. Severe chronic pain is associated with increased 10 year mortality. A cohort record linkage study. Eur J Pain 2010;14:380-6.

4. Raftery MN, Sarma K, Murphy AW, De la Harpe D, Normand C, McGuire BE. Chronic pain in the Republic of Ireland--community prevalence, psychosocial profile and predictors of pain-related disability: results from the Prevalence, Impact and Cost of Chronic Pain (PRIME) study, part 1. Pain 2011;152:1096-103.

5. Bedson J, Croft PR. The discordance between clinical and radiographic knee osteoarthritis: a systematic search and summary of the literature. BMC Musculoskelet Disord 2008;9:116.

6. Imamura M, Imamura ST, Kaziyama $\mathrm{HH}$, Targino RA, Hsing WT, de Souza LP, et al. Impact of nervous system hyperalgesia on pain, disability, and quality of life in patients with knee osteoarthritis: a controlled analysis. Arthritis Rheum 2008;59:1424-31.

7. Mallen CD, Peat G, Thomas E, Dunn KM, Croft PR. Prognostic factors for musculoskeletal pain in primary care: a systematic review. Br J Gen Pract 2007;57:655-61.

8. Nahit ES, Pritchard CM, Cherry NM, Silman AJ, Macfarlane GJ. The influence of work related psychosocial factors and psychological distress on regional musculoskeletal pain: a study of newly employed workers. J Rheumatol 2001;28:1378-84.

9. Ustün TB, Chatterji S, Kostanjsek N, Rehm J, Kennedy C, Epping-Jordan J, et al. Developing the World Health Organization Disability Assessment Schedule 2.0. Bull World Health Organ 2010;88:815-23.

10. Tait RC, Chibnall JT, Krause S. The Pain Disability Index: psychometric properties. Pain 1990;40:171-82.

11. Pain terms: a list with definitions and notes on usage. Recommended by the IASP Subcommittee on Taxonomy. Pain 1979;6:249.

12. Guillemin F, Bombardier C, Beaton D. Cross-cultural adaptation of health-related quality of life measures: literature review and proposed guidelines. J Clin Epidemiol 1993;46:1417-32.

13. Beaton DE, Bombardier C, Guillemin F, Ferraz MB. Guidelines for the process of cross-cultural adaptation of self-report measures. Spine (Phila $\mathrm{Pa}$ 1976) 2000;25:3186-91.

14. Huskisson EC. Measurement of pain. Lancet 1974;2:1127-31.

15. Stewart AL, Hays RD, Ware JE Jr. The MOS shortform general health survey. Reliability and validity in a patient population. Med Care 1988;26:724-35.

16. Kaplan İ. Yarı kırsal alanda bir sağlık ocağına başvuran hastalarda ruhsal bozuklukların yeti yitimi ile ilişkisi. Türk Psikiyatri Dergisi 1995;6:169-79.

17. McHorney CA, Tarlov AR. Individual-patient monitoring in clinical practice: are available health status surveys adequate? Qual Life Res 1995;4:293307.

18. Tait RC, Pollard CA, Margolis RB, Duckro PN, Krause SJ. The Pain Disability Index: psychometric and validity data. Arch Phys Med Rehabil 1987;68:43841.

19. Grönblad M, Hupli M, Wennerstrand $P$, Järvinen $E$, Lukinmaa A, Kouri JP, et al. Intercorrelation and test-retest reliability of the Pain Disability Index (PDI) and the Oswestry Disability Questionnaire (ODQ) and their correlation with pain intensity in low back pain patients. Clin J Pain 1993;9:189-95.

20. Marbouti L, Jafari H, Noorizadeh-Dehkordi S, Behtash H. Pain-related disability measurement: the cultural adaptation and validation of "pain disability index (PDI)" and "pain disability questionnaire (PDQ)" among Iranian low back pain patients. Med J Islam Repub Iran. 2011;25:27-34.

21. Mohamad Ghazali M, Isa KAM, Nor Adilah Abdul W. Translation of the Pain Disability Index (PDI) to Malay with reliability evaluation and validation. International Conference on Science and Social Research (CSSR), 2010. p. 504-9.

22. Gauthier N Thibault P, Adams H, Sullivan MJ. Validation of a French-Canadian version of the Pain Disability Index. Pain Res Manag 2008;13:327-33.

23. Soer R, Köke AJ, Vroomen PC, Stegeman P, Smeets RJ, Coppes $\mathrm{MH}$, et al. Extensive validation of the pain disability index in 3 groups of patients with musculoskeletal pain. Spine (Phila Pa 1976) 2013;38:562-8.

24. Chin WW. The partial least squares approach to structural equation modeling. Modern Methods for Business Research 1998;295:295-336.

25. Bicer A, Yazici A, Camdeviren H, Milcan A, Erdogan C. Assessment of pain and disability in patients with chronic low back pain: reliability and construct validity of the Turkish version of the Quebec Back Pain Disability Scale and Pain Disability Index. J Back Musculoskelet 2005;18:37-44. 


\section{Appendix}

\section{AĞRIYA BAĞLI YETIYITIMI INDEKSi}

Adl/Soyadi:

Tarih:

Bu ölçek, ăğrı nedeniyle hayatınızda yaşadığınız zorlukların derecesini değerlendirmek için geliştirilmiştir. Başka bir ifadeyle, ağrının normalde yaptığınız ya da yapmak istediğiniz şeyleri ne kadar engellediğini öğrenmek istiyoruz. Her bir bölümde, sadece ağrının en şiddetli olduğu zamanları düşünerek değil, ağrının yaşamınızdaki tüm etkilerini düşünerek işaretleme yapınız.

Aşağıda sıralanan 7 günlük aktivite alanlarının her biri için, sıklıkla yaşadığınız zorlanma derecesini gösterecek şekilde, ölçek üzerindeki sayıyı daire içine alınız. 0 puan hiçbir zorlanma olmadığını, 10 puan ise normalde yapabildiğiniz tüm günlük aktivitelerin ağrı nedeniyle engellenmesi ya da tamamen kesintiye uğraması anlamına gelmektedir.

Aile/Ev Sorumlulukları: Bu bölüm aile ve ev yaşantısına dair aktivitelerle ilgilidir. Günlük ev işleri, evin yakın çevresi ile ilgili işler (bahçe işleri gibi), getir götür işleri (alışveriş gibi) ya da diğer aile üyelerinin bakımı konusunda yapılan işler (çocukları okula hazırlamak, bırakmak veya okuldan almak gibi) bu kapsamda değerlendirilir.
Hiç zorluk yok 0
2
3
4
$5 \quad 6$
7
8
9
10 Aşırı zorlanma var

Boş Vakitleri Değerlendirme: Bu bölüm hobileri, spor faaliyetlerini ve buna benzer diğer boş vakitlerde yapılan faaliyetleri içerir.
Hiç zorluk yok 0
2
3
$4 \quad 5$
6
7
8
9
10 Aşırı zorlanma var

Sosyal Aktiviteler: Bu bölüm aile üyeleri dışında, arkadaş ve tanıdıklarla beraber yapılan faaliyetleri içerir. Bunların arasında ev toplantıları, tiyatro, konser, dişarıda yemek yeme ve diğer sosyal faaliyetler sayılabilir.
Hiç zorluk yok 0
2
3
4
56
7
89
10 Aşırı zorlanma var

Mesleki Aktiviteler: Bu bölüm bir kişinin kısmen ya da tamamen işiyle ilgili olan faaliyetleri kapsar. Ev hanımı olmak ya da gönüllü olarak yapılan ve gelir getirmeyen işler de bu alanda değerlendirilir.
Hiç zorluk yok 0
2
3
4
5
6
7
89
10 Așırı zorlanma var

Cinsel Yaşam: Bu bölüm bir kişinin cinsel yaşamının kalitesini ve sıklığını belirtmek içindir.
Hiç zorluk yok 0
2
34
5
6
$7 \quad 8$
9
10 Așırı zorlanma var

Kendine Bakım: Bu bölüm kişisel ihtiyaçları giderebilme ve başkalarından destek almadan günlük yaşamsal aktiviteleri (örneğin; banyo yapmak, araç kullanmak, giyinmek vb. gibi) yapabilmeyi kapsar.
Hiç zorluk yok 0
2
3
45
6
7
8
9
10 Aşırı zorlanma var

Temel İhtiyaçlar: Bu bölüm yaşamı sürdürebilmek için gerekli olan, yemek yeme, uyuma gibi bazı temel davranışları içerir.
Hiç zorluk yok 0
4
5
6
7
8
9
10 Aşırı zorlanma var 